\title{
The effect of cadmium on the growth and antioxidant response for freshwater algae Chlorella vulgaris
}

\author{
Jinfeng Cheng ${ }^{1 *}$, Hongchen Qiu $^{2}$, Zhaoyang Chang ${ }^{1}$, Zaimin Jiang ${ }^{1}$ and Wenke Yin ${ }^{1}$
}

\begin{abstract}
The objective of the present work was to evaluate the effect of exogenously applied cadmium on the physiological response of green algae Chlorella vulgaris. The study investigated the long-term effect (18 days) of cadmium on the levels of algae biomass, assimilation pigment composition, soluble protein, oxidative status (production of hydrogen peroxide and superoxide anion), antioxidant enzymes (such as superoxide dismutase, peroxidase, catalase and glutathione reductase enzyme) in C. vulgaris. The results showed that growth, the amount of chlorophyll a (Chla), chlorophyll $b(C h / b)$ and carotenoids gradually decreased with increasing cadmium over 18 days exposure. Cadmium at concentration of $7 \mathrm{mg} \mathrm{L}^{-1}$ inhibited algal growth expressed as the number of cells. Our research found that $C$. vulgaris has a high tolerance to cadmium. Contents of chlorophylls ( $C h / a$ and $C h / b)$ and carotenoids (Car) of C. vulgaris was significantly decline with rising concentration of cadmium ( $p<0.05$ ). The decrease of 54.04 and $93.37 \%$ in Chl a, 60.65 and $74.32 \%$ in Chl b, 50.00 and $71.88 \%$ in total carotenoids was noticed following the treatment with 3 and $7 \mathrm{mg} \mathrm{L}^{-1}$ cadmium doses compared with control treatment, respectively. Cadmium treatments caused a significant change in the physiological competence (calculated as chlorophyll $a / b$ ) which increased with increasing $C d(I)$ doses up to $1 \mathrm{mg} \mathrm{L}^{-1}$ but decreased at $3 \mathrm{mg} \mathrm{L}^{-1}$. While accumulation of soluble protein was enhanced by presence of cadmium, the treatment with cadmium at 3 and $7 \mathrm{mg} \mathrm{L}^{-1}$ increased the concentration of soluble proteins by $88,95.8 \%$ in $C$. vulgaris, respectively. Moreover, low doses of cadmium stimulated enzymatic (superoxide dismutase, catalase and glutathione reductase) in C. vulgaris, The content of peroxidase increased with the increasing cadmium concentration, and had slightly decreased at the concentration of $7 \mathrm{mg} \mathrm{L}^{-1}$, but was still higher than control group, which showed that cadmium stress at high concentration mainly peroxidase works in C. vulgaris. And therefore, suppressed reactive oxygen species (hydrogen peroxide and superoxide) accumulated. The present study also showed that cadmium increased oxidative stress and induced antioxidant defense systems against reactive oxygen species. The observation in here analyzed C. vulgaris after exposure to cadmium indicate that hydrogen peroxide, superoxide and peroxidase in the alga with exposure to $\mathrm{Cd}(\mathrm{II})$ seemed to be parameters as biomarkers for metal-induced oxidative stress.
\end{abstract}

Keywords: Chlorella vulgaris, Cadmium, Reactive oxygen species (ROS), Antioxidant enzymes

\section{Background}

Heavy metals are important environmental pollutants, water environmental deterioration caused by heavy metal emissions are increasing, and produce toxic effects on aquatic plants. The bioaccumulation of metals is a useful

\footnotetext{
${ }^{*}$ Correspondence: chengjinfeng@nwsuaf.edu.cn

1 The College of Life Sciences, Northwest A\&F University, Yangling 712100, Shaanxi, China

Full list of author information is available at the end of the article
}

indicator since metals are not metabolized (Luoma and Rainbow 2005). Heavy metal can accumulate in aquatic animals and aquatic plants, not only effect the growth and development of aquatic animals and aquatic plants seriously, but also may enter the food chain and endanger human health. Algae are the primary producers of water, heavy metals and other pollutants which into the water through various means are first act on the algae, algae-rich contaminants and affect the entire aquatic ecosystem by pass through the food chain (Liu et al. 2008). 
Recent studies show that algae can enrich metal ions, we can use algae to repair heavy metal contaminated water. Study the algae physiological response mechanism in heavily stress conditions, to explore the mechanism of resistance to heavy metals, can provide a reference for better used in the treatment of heavy metal wastewater. Under normal metabolic process, the enzymatic and non-enzymatic protection system can make the production and eliminate of ROS maintain homeostasis. When subjected to environmental stress, such as, strong light (Romanowska et al. 2008), ultraviolet radiation (Zhang et al. 2005; Schmidt et al. 2011) and heavy metal stress (Dai 2012), will produce reactive oxygen species (ROS), such as superoxide $\left(\mathrm{O}_{2}^{-\cdot}\right)$, hydroxide $\left(\mathrm{OH}^{-}\right)$, hydroxyl radical $(\cdot \mathrm{OH})$, hydrogen peroxide $\left(\mathrm{H}_{2} \mathrm{O}_{2}\right)$. Heavy metal has some toxicity; trace amounts of heavy metals can produce toxic effects. Stress leads to plants produce large amounts of reactive oxygen species. ROS can directly damage proteins, amino acids, nucleic acids and membrane lipids. The antioxidant protection system like the superoxide dismutase (SOD), peroxidase (POD), catalase (CAT), glutathione reductase enzyme (GR), et al can remove the excess ROS induced by stress, protecting cells against injury (Zhou et al. 2001). SOD is the first key enzyme to scavenging reactive oxygen species in plants; in organisms it is in an important position in the active oxygen metabolism, which can disproportionate $\mathrm{O}_{2}{ }^{-}$to be $\mathrm{H}_{2} \mathrm{O}_{2}$, thereby protecting cells oxidative free radical damage. POD is also one of a plant antioxidant enzyme defense system, its active can reflect the intensity of antioxidant capacity and the severity of poisoned of plants, and can catalyze the decomposition the toxic substances in a certain range (Zhang et al. 2002). And POD able to restore $\mathrm{H}_{2} \mathrm{O}_{2}$ into $\mathrm{H}_{2} \mathrm{O}$. CAT is also a ubiquitous enzyme that can remove $\mathrm{H}_{2} \mathrm{O}_{2}$ generated in the metabolism in plant. GR plays an important role in the glutathione cycle metabolism, plants can resistant oxidative metabolism by glutathione metabolic cycle. And under stress, the morphology, growth, photosynthetic pigments, cell biology and physiology of algal were also affected (Bouzon et al. 2011; Schmidt et al. 2011).

Chlorella vulgaris is Chlorophyceae, single-cell green freshwater algae, the diameter is $3-8$ microns, is a highly efficient photosynthetic plants, and one of the earliest life on earth, is commonly found in freshwater ecosystems. Survival of the green algae in the aquatic environment contaminated with metals depends on its ability to generate and transit signals that adjust the metabolism. Biomarkers can be used to evaluate the ecological risk assessment (Çelekli et al. 2016). Chlorella vulgaris has strong ability to adapt to the environment. In our previous study of the chlorella, our research found that $C$. vulgaris has a high tolerance to cadmium. Cadmium is one of the most toxic metals. The major sources of cadmium release into the environment by waste streams are electroplating, smelting, alloy manufacturing, pigments, plastic, battery, mining, and refining processes (Gülay and Yakup 2011). But we found that the study on effect of physiological and antioxidant enzymes on $C$. vulgaris by cadmium is less.

In view of this, the present study was designed to investigate the extent of Cd-induced oxidative stress in C. vulgaris. The effect of various cadmium concentration on $C$. vulgaris growth, pigments, hydrogen peroxide $\left(\mathrm{H}_{2} \mathrm{O}_{2}\right)$, superoxide anion $\left(\mathrm{O}_{2}^{--}\right)$, SOD, POD, CAT and GR have been investigated. Provide evidence of physiological mechanisms in the aspects of response cadmium stress by plants. The effect of cadmium on algae growth and antioxidant system and the physiological of $C$. vulgaris response to cadmium stress were analyzed, it aimed to further explore the mechanism of metal toxicity to algae and the mechanism of resistance to heavy metals.

\section{Methods}

Clonal culture of $C$. vulgaris was established by micropipette isolation of a single cell from the water sample which was collected from freshwater, Shaanxi Province, China. Cultures were grown under sterile conditions on glass triangular flask with BG11 medium (Stanier et al. 1971). Cultures were maintained at $20{ }^{\circ} \mathrm{C}$ under $12 \mathrm{~h}$ light: $12 \mathrm{~h}$ dark (L: D) cycle and at an illumination of $75 \mu \mathrm{mol}$ photons $\mathrm{m}^{-2} \mathrm{~s}^{-1}$.

Cells were harvested by centrifugation at exponential phase, collected algae (which density was $3 \times 10^{4}$ cells $\mathrm{mL}^{-1}$ ) were enriched in triplicate with varying $\mathrm{Cd}(\mathrm{II})$ supplements in the final concentrations of $0.0,0.5,1,3,5,7 \mathrm{mg} \mathrm{L}^{-1}$. In all cases, $3 \mathrm{CdSO}_{4} \cdot 8 \mathrm{H}_{2} \mathrm{O}$ was used.

\section{Determination of cell growth}

Subsamples for cell counting $(2 \mathrm{~mL})$ and metal concentration were taken at approximately the same time every day. Samples for enumeration were fixed in Lugo's solution (final concentration $2 \%$ ) and counted in Sedgewick rafter chamber. Biomass is represented by the number of algae (Lundholm et al. 2004).

\section{Measurement of pigments}

The chlorophyll was extracted in the dark for $1 \mathrm{~h}$ at $65^{\circ} \mathrm{C}$ in $5 \mathrm{~mL}$ DMSO. After cooling to room temperature and centrifuged at $15,000 \mathrm{~g}$ for $15 \mathrm{~min}$. The chlorophyll content was estimated according to the equations proposed by Wellburn (1994) using a spectrophotometer at 666, 653, and $750 \mathrm{~nm}$ to correct unspecific absorption (Jozef and Martin 2007). To determine the content of "total" carotenoids, absorbance was read at $480 \mathrm{~nm}$. Chl a, Chl 
$b$, chlorophyll $a+\mathrm{b}$ and total carotenoids were calculated using equations derived from specific absorption coefficients for pure Chl $a$ and Chl $b$ in DMSO (Wellburn 1994). Chlorophyll $a / b$ was used to assess the physiological competence of algal cells.

\section{Measurement of soluble protein}

Soluble protein was measured according to Coomassie Brilliant Blue G-250 method (Bradford 1976). Proteins were extracted with $50 \mathrm{mM}$ potassium phosphate buffer ( $\mathrm{pH}$ 7.0) and estimated using bovine serum albumin as standard. After centrifugation at $5000 \mathrm{~g}$ at $4{ }^{\circ} \mathrm{C}$ for $10 \mathrm{~min}$, the water-soluble protein content of supernatants was measured. Supernatants $(1 \mathrm{~mL})$ were added into $5 \mathrm{~mL}$ Coomassie Brilliant Blue G-250 and mixed thoroughly. After $10 \mathrm{~min}$, absorbance of samples $(2 \mathrm{~mL})$ was spectrophotometrically measured at $595 \mathrm{~nm}$. Each treatment was replicated three times.

\section{Detection of hydrogen peroxide and superoxide anion} Hydrogen peroxide was extracted by potassium phosphate buffer ( $\mathrm{pH}$ 6.5).Hydrogen peroxide was quantified by the $\mathrm{TiCl}_{4}$ method (Jozef et al. 2009). Phosphate buffer (50 mM, pH: 6.5) was added into crushed culture. After centrifugation, $0.1 \%$ titanium chloride in $20 \% \mathrm{H}_{2} \mathrm{SO}_{4}$ $(1.5 \mathrm{~mL})$ was added into supernatant $(3 \mathrm{~mL})$ and mixed thoroughly. After centrifugation at $15,000 \mathrm{~g}$ at $4{ }^{\circ} \mathrm{C}$ for $20 \mathrm{~min}$. Absorbance was spectrophotometrically measured at $410 \mathrm{~nm}$. The amount of $\mathrm{H}_{2} \mathrm{O}_{2}$ was calculated from standardized curve $(0.6-1.8 \mathrm{mM}) \mathrm{H}_{2} \mathrm{O}_{2}$ in buffer plus $0.5 \mathrm{~mL}$ of titanium chloride solution).

Superoxide anion was extracted by potassium phosphate buffer ( $\mathrm{pH} 7.8$ ) and estimated according to Sun and $\mathrm{Hu}(2005)$ by monitoring at $530 \mathrm{~nm}$ using $\mathrm{NaNO}_{3}$ as standard. Phosphate buffer (65 mM, pH: 7.8) were added into crushed algae solution and then centrifuged. Reaction mixture contained $2 \mathrm{~mL}$ of supernatant, $1.5 \mathrm{~mL}$ of phosphate buffer, $0.5 \mathrm{~mL}$ of hydroxylamine hydrochloride, after mixing, bathed at $25{ }^{\circ} \mathrm{C}$ water for $20 \mathrm{~min}$, took $2 \mathrm{~mL}$ reaction solution, added $2 \mathrm{~mL}$ of sulfanilic and $2 \mathrm{~mL}$ of $\alpha$-naphthylamine, bathed at $30{ }^{\circ} \mathrm{C}$ water for $30 \mathrm{~min}$, and measured at $530 \mathrm{~nm}$. Each treatment was replicated three times.

\section{Determination of enzyme activity}

Peroxidase (POD) activity was measured according to guaiacol oxidation method (Gao 2005). Each sample had divided into the measuring tube and the blank tube, added with enzyme solution, $0.1 \%$ guaiacol, distilled water, $0.18 \% \mathrm{H}_{2} \mathrm{O}_{2}$ (blank tube was not added), accurately react $10 \mathrm{~min}$ under $25{ }^{\circ} \mathrm{C}, 5 \%$ metaphosphoric acid was added to terminate the reaction, measuring the absorbance under $470 \mathrm{~nm}$.
Superoxide dismutase (SOD) activity was determined by tetrazolium reduction method (Gao 2005). One SOD unit was defined as the amount of enzyme required for inhibit $50 \%$ of NBT photoreduction. Each sample was divided into three tubes, the measuring tube, the light control tube and the dark control tube respectively. Each tube was added with $550 \mathrm{mmol} \mathrm{L}^{-1}$ potassium phosphate buffer ( $\mathrm{pH} 7.8$ ), $130 \mathrm{mmol} \mathrm{L}^{-1}$ methionine solution, $750 \mu \mathrm{mol} \mathrm{L}^{-1}$ NBT solution, $20 \mu \mathrm{mol} \mathrm{L}^{-1}$ riboflavin solution, $100 \mu \mathrm{mol} \mathrm{L}{ }^{-1}$ EDTA- $\mathrm{Na}_{2}$, distilled water, and the enzyme solution was added to the measuring tube, the same amount of distilled water was added to the other tubes. Then the tubes were placed under 1000Lx Fluorescent color reaction $15 \mathrm{~min}$, covered with a black cloth to termination the reactions, make the dark control tube as a blank control and measured the absorbance at $560 \mathrm{~nm}$.

Catalase (CAT) activity was determined using UV absorption method (Gao 2005), to reduce 0.1 within 1 min under A 240 was taken as an enzyme activity unit(U). Each sample had two tubes, added with Tris$\mathrm{HCl}$ buffer ( $\mathrm{pH} 7.0)$, distilled water, one tub was added with live enzymes, another was dead enzyme, preheat 3 min using a water bath at $25{ }^{\circ} \mathrm{C}$, adding $200 \mathrm{mmol} \mathrm{L}^{-1}$ $\mathrm{H}_{2} \mathrm{O}_{2}$ and measuring the absorbance under A240 (distilled water zero) immediately.

Glutathione reductase (GR) activity was determined using the method of Schaedle (1977). To decreases 0.1 at A340 per milligram per minute was taken as an enzyme activity. GR catalyze following reaction: $\mathrm{GSSH}+\mathrm{NADPH} \rightarrow \mathrm{GSH}+\mathrm{NADP}^{+}$. GR activity was determined by measuring the change of NADPH. $1 \mathrm{~mL}$ reaction mixture containing $50 \mathrm{mmol} \mathrm{L}^{-1}$ potassium phosphate buffer (pH 7.8), $20 \mathrm{mmol} \mathrm{L}^{-1}$ EDTA, $1.5 \mathrm{mM}$ NADPH, $5 \mathrm{mM}$ GSSG, $200 \mu \mathrm{L}$ enzyme solution, and measured the change of OD340 in $1 \mathrm{~min}$ under $20{ }^{\circ} \mathrm{C}$ immediately (extinction coefficient is $6.2 \mathrm{mmol} \mathrm{L}^{-1} \mathrm{~cm}^{-1}$ ).

All determinations were made in triplicate and data are expressed as means \pm the standard deviation (SD). Statistical tests were carried out using the software SPASS ver. Differences between individual means were determined by Tukey's post hoc multiple range test $\mathrm{p}<0.05$ for this procedure.

\section{Results}

Dose-effect of cadmium in C. vulgaris growth and composition of pigments

Growth measured as cell density (Fig. 1). There were significant differences in the cell density of $C$. vulgaris under high $\mathrm{Cd}(\mathrm{II})$ treatments and cell density decreased in response to increasing cadmium doses, as shown in Fig. 1 . The inhibited growth was mainly occurred under high cadmium concentration $\left(3 \mathrm{mg} \mathrm{L}^{-1}, 5 \mathrm{mg} \mathrm{L}^{-1}\right), C$. 


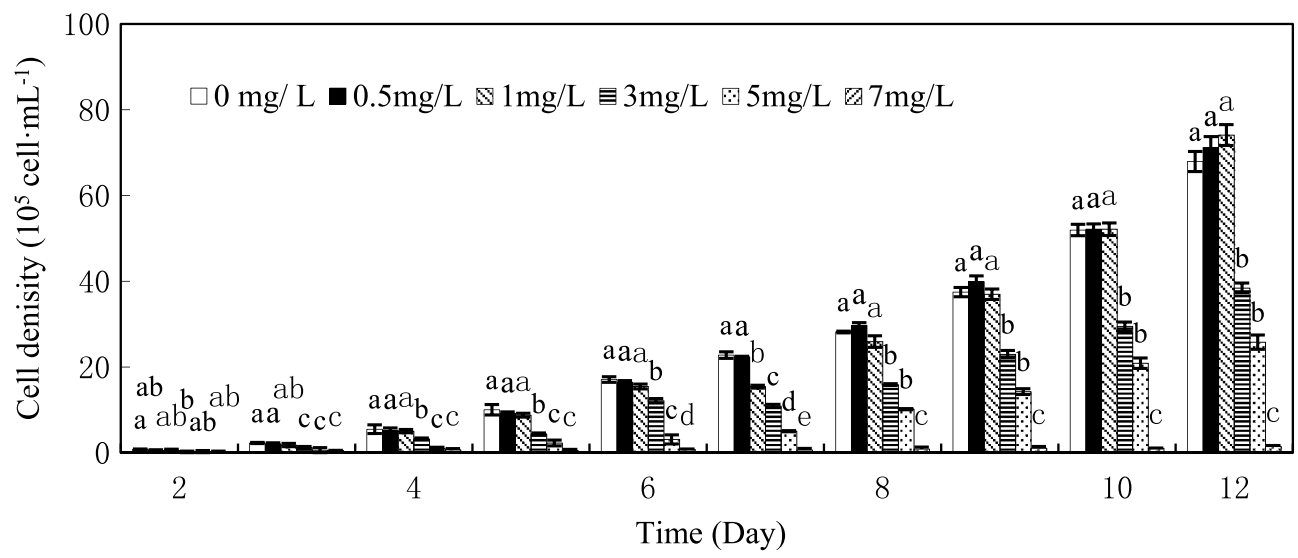

Fig. 1 Cells density $\left(10^{5}\right.$ cells $\left.\mathrm{mL}^{-1}\right)$ of $C$. vulgaris under various $\mathrm{Cd}(\mathrm{II})$ concentrations. Different lowercase letter (a-e) indicate significant differences between treatments exposed to increasing metal concentration $(p<0.05)$. Values in columns followed by the same letter(s) are not significantly different according to Tukey's test $(p<0.05)$

vulgaris could not be survived in $7 \mathrm{mg} \mathrm{L}^{-1}$ cadmium concentration. But under low cadmium supplements, there was barely no inhibited even slightly promotion after 12 days, and the effect was not obvious. The result indicted that $C$. vulgaris can be well tolerated with 1-5 $\mathrm{mg} \mathrm{L}^{-1}$ cadmium, although the growth is inhibited under high concentration, $C$. vulgaris still can be lived in $5 \mathrm{mg} \mathrm{L}^{-1}$. Our research found that $C$. vulgaris has a high tolerance to cadmium.

Effects of cadmium stress on Chl $a, C h l b$ and total carotenoids of $C$. vulgaris are presented in Fig. 2. Cadmium had an adverse influence on Chl a production by $C$. vulgaris. The Chl a content significantly

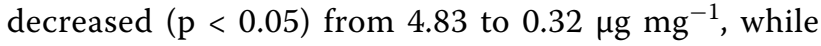
the $\mathrm{Cd}(\mathrm{II})$ concentration was increased from 0 (control) to $7 \mathrm{mg} \mathrm{L}^{-1}$. A similar tendency was observed for Chl $b$ upon cadmium exposure (Fig. 2). The total carotene production by $C$. vulgaris varied from 0.64 to $0.18 \mu \mathrm{g} \mathrm{mg}^{-1}$ for the control and $7 \mathrm{mg} \mathrm{L}^{-1} \mathrm{Cd}(\mathrm{II})$, respectively. $\mathrm{Cd}(\mathrm{II})$ had an adverse effect $(\mathrm{p}<0.05)$ on the total carotene production. The decrease of 54.04 and $93.37 \%$ in Chl $a, 60.65$ and $74.32 \%$ in $C h l b, 50.00$ and $71.88 \%$ in total carotenoids was noticed following the treatment with 3 and $7 \mathrm{mg} \mathrm{L}^{-1}$ cadmium doses compared with control treatment, respectively. Cadmium treatments caused a significant change in the physiological competence (calculated as chlorophyll $a / b)$ which increased with increasing $\mathrm{Cd}(\mathrm{II})$ doses up to $1 \mathrm{mg} \mathrm{L}^{-1}$ but decreased at $3 \mathrm{mg} \mathrm{L}^{-1}$. Chl $a$ to Chl $b$ ratios revealed that the damaging effect was found to be greater (by $42.6 \%$ ) on Chl $b$ at $1 \mathrm{mg} \mathrm{L}^{-1} \mathrm{Cd}(\mathrm{II})$ concentration while $C h l a$ was affected more (by $93.4 \%$ ) under $7 \mathrm{mg} \mathrm{L}^{-1} \mathrm{Cd}(\mathrm{II})$ concentration.
The effect of cadmium on soluble protein content, hydrogen peroxide and superoxide anion content of $C$. vulgaris

The influence of $\mathrm{Cd}(\mathrm{II})$ stress on protein, hydrogen peroxide and superoxide anion contents of $C$. vulgaris is given in Fig. 3. After 18 days exposure, effect of different $\mathrm{Cd}(\mathrm{II})$ concentrations on soluble protein content was significantly altered. Cd(II) stress had a significantly increasing trend on the protein content of $C$. vulgaris under the concentration $0-7 \mathrm{mg} \mathrm{L}^{-1}$ (Fig. 3).The effect of Cd(II) on hydrogen peroxide and superoxide anion were both significant ( $\mathrm{p}<0.001$ ) (Fig. 3). Levels of hydrogen peroxide and superoxide anion elevated with increasing $\mathrm{Cd}$ content in the medium, significantly under the high concentration of 5 and $7 \mathrm{mg} \mathrm{L}^{-1}$, the hydrogen peroxide contents were increased by 5.90 times and 7.45 times, and superoxide anion were increased by 9.70 times and 14.59 times at 5 and $7 \mathrm{mg} \mathrm{L}^{-1} \mathrm{Cd}(\mathrm{II})$ concentration, respectively. The highest contents of these ROS were observed in C. vulgaris cells treated with $7 \mathrm{mg} \mathrm{L} \mathrm{L}^{-1} \mathrm{Cd}(\mathrm{II})$ concentration (7.45 times increase in hydrogen peroxide content, and 14.59 times increase in superoxide anion content) in the 18 days of cultivation.

\section{Activity of antioxidative enzymes}

Antioxidant biomarkers, $\mathrm{Cd}$ had significant effects on the activities of antioxidant enzymes at most of the experimental doses in comparison with the controls. Cadmium influenced the activity of antioxidant enzymes (SOD, POD, CAT and GR) involved in the scavenging of ROS (Figs. 4, 5, 6). Effect of different concentrations of cadmium on four enzymes was significant. The contents of SOD, CAT, GR were all first increases and then decrease 


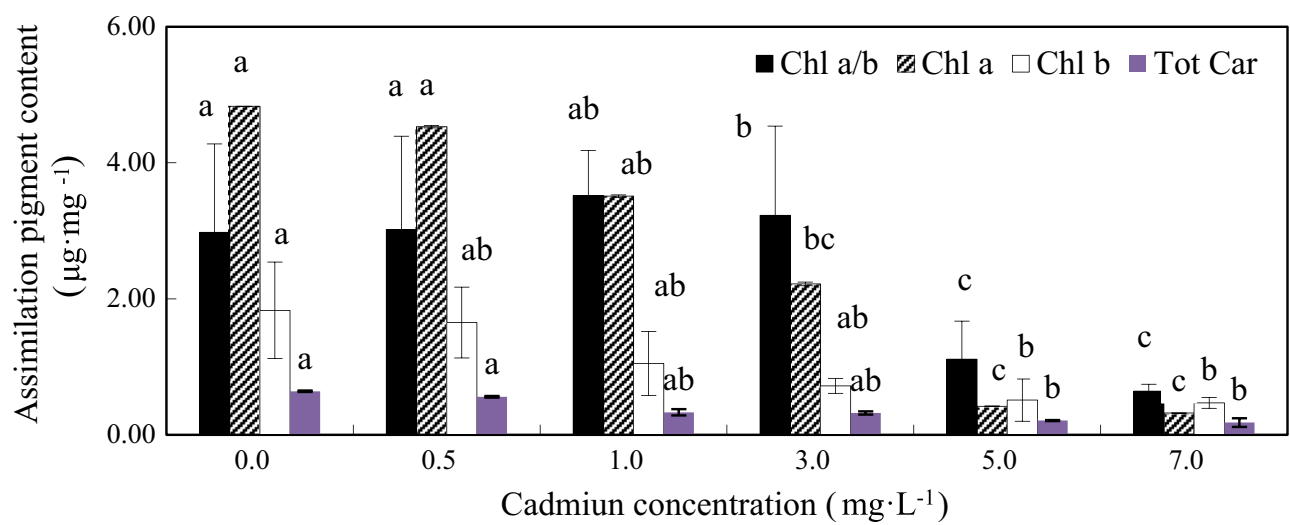

Fig. 2 Assimilation pigment composition of $C$. vulgaris cultivated for 18 days in $\mathrm{Cd}(\mathrm{II})$ medium. Different lowercase letter ( $a-c)$ indicate significant differences between treatments exposed to increasing metal concentration $(p<0.05)$. Values in columns followed by the same letter(s) are not significantly different according to Tukey's test $(p<0.05)$

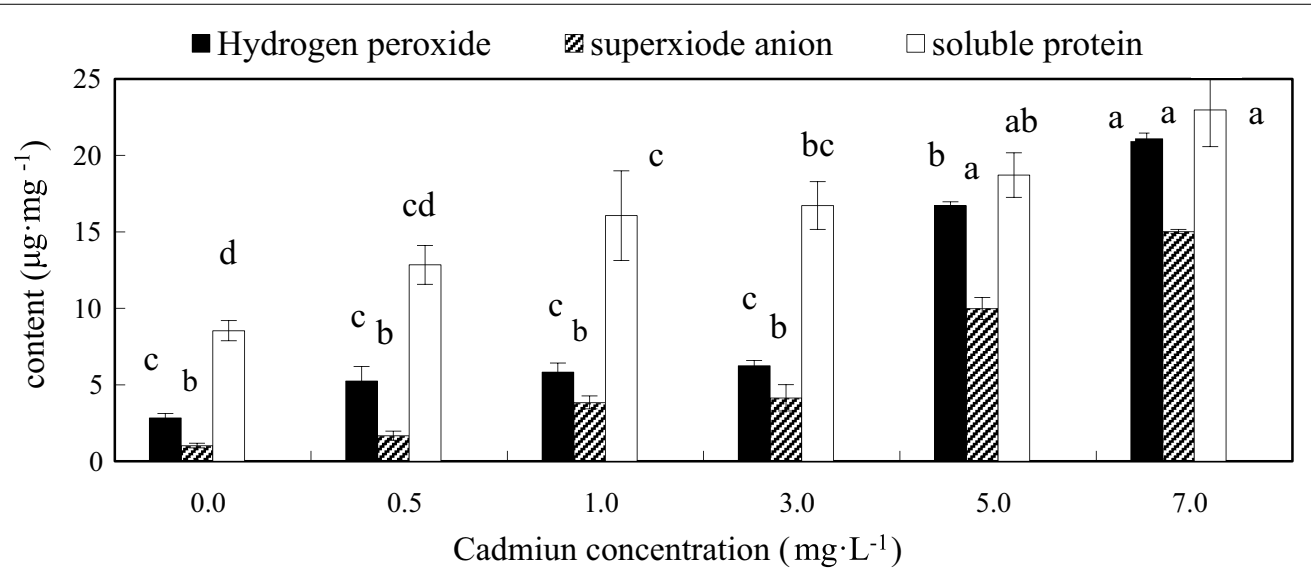

Fig. 3 Contents of soluble protein, hydrogen peroxide and superoxide anion of $C$. vulgaris cultivated 18 days. Different lowercase letter ( $a-c$ ) indicate significant differences between treatments exposed to increasing metal concentration $(p<0.05)$. Values in columns followed by the same letter(s) are not significantly different according to Tukey's test $(p<0.05)$

with the cadmium concentration increasing, SOD and CAT content reached a maximum at $0.5 \mathrm{mg} \mathrm{L}^{-1}$ (Fig. 4), GR content reached a maximum at $1 \mathrm{mg} \mathrm{L}^{-1}$ (Fig. 6). The highest enhancement of the activity of antioxidant enzymes ( $34.18 \%$ SOD, $38.79 \%$ CAT) appeared as a consequence of algal exposure to $0.5 \mathrm{mg} \mathrm{L}^{-1}$ cadmium after 18 days of cultivation. Cadmium applied $1 \mathrm{mg} \mathrm{L}^{-1}$ stimulated the activity of GR by $92.38 \%$. The content of POD increased with the increasing cadmium concentration, and had slightly decreased at the concentration of $7 \mathrm{mg} \mathrm{L}{ }^{-1}$, but was still higher than control group. The increase in POD level by 1.45 times, 1.26 times, 2.50 times, 3.06 times and 2.40 times was obtained in the culture growing in the presence of $0.5,1,3,5$, and $7 \mathrm{mg} \mathrm{L}^{-1}$ cadmium, respectively after 18 days of cultivation (Fig. 5). Results indicated that, $0.5 \mathrm{mg} \mathrm{L}^{-1}$ cadmium stimulated
SOD by $34.18 \%$, CAT by $38.79 \%, 1 \mathrm{mg} \mathrm{L}^{-1}$ cadmium enhanced the activity of GR by $92.38 \%$, whereas cadmium increased the activity of POD after 18 days of cultivation. And showed that cadmium stress at high concentration mainly POD works in C. vulgaris.

\section{Discussion}

Decrease of the growth can be relatively easily determined and reflects physiological status of the algal cells (Juraj et al. 2011). Heavy metals had adverse effects on the growth of Scenedesmus quadricauda (Mohammed and Markert 2006; Stork et al. 2013) and Spirogyra setiformis (Çelekli et al. 2016) in cultures, same result also was found in this study, the inhibited of growth is mainly under high cadmium concentration, the growth of $C$. vulgaris decreased with the increasing cadmium concentration. 


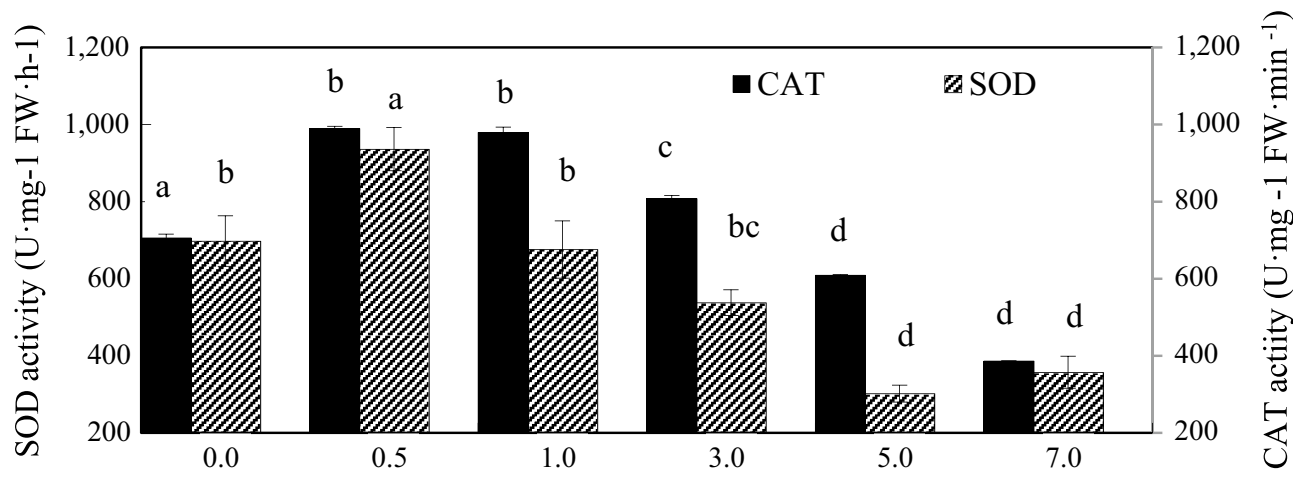

Cadmiun concentration $\left(\mathrm{mg} \cdot \mathrm{L}^{-1}\right)$

Fig. 4 Contents of SOD and CAT of C. vulgaris cultivated 18 days C. vulgaris in Cd(II) medium. Different lowercase letter (a-e) indicate significant differences between treatments exposed to increasing metal concentration $(p<0.05)$. Values in columns followed by the same letter $(s)$ are not significantly different according to Tukey's test $(p<0.05)$

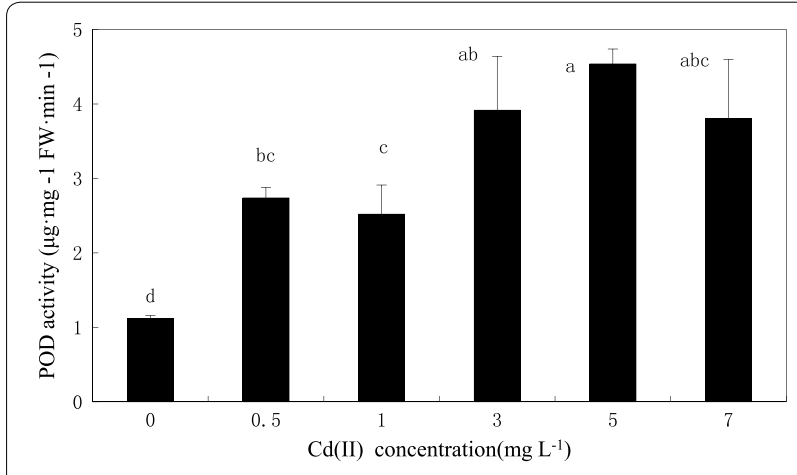

Fig. 5 Contents POD of $C$. vulgaris cultivated 18 days in cadmium in $\mathrm{Cd}(\mathrm{II})$ medium. Different lowercase letter $(a-e)$ indicate significant differences between treatments exposed to increasing metal concentration $(p<0.05)$. Values in columns followed by the same letter $(s)$ are not significantly different according to Tukey's test $(p<0.05)$

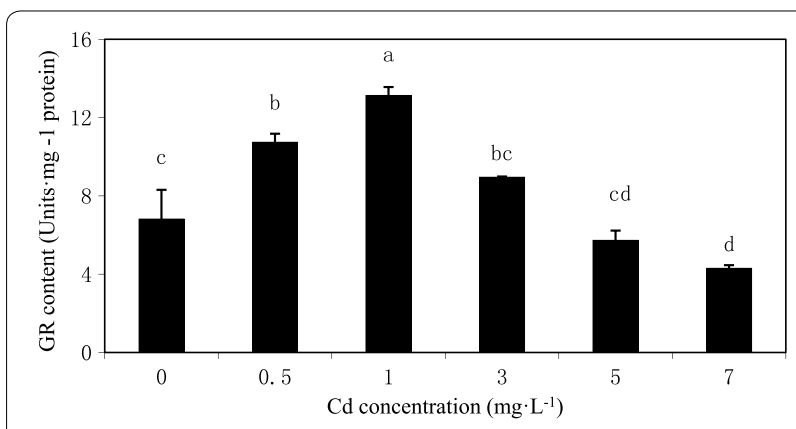

Fig. 6 Contents GR of C. vulgaris cultivated 18 days in cadmium in $\mathrm{Cd}(\mathrm{II})$ medium. Different lowercase letter ( $a-e)$ indicate significant differences between treatments exposed to increasing metal concentration $(p<0.05)$. Values in columns followed by the sameletter $(s)$ are not significantly different according to Tukey's test $(p<0.05)$
Pigment reduction was reported for S. quadricauda exposed to $\mathrm{Cu}$ (Kováčik et al. 2010) C. pyrenoidosa with perfluorooctanoic acid exposure (Xu et al. 2013), S. obliquus exposed to $\mathrm{Cu}$ (Chen et al. 2012) and carbamazepine (Zhang et al. 2012), and C. vulgaris exposed to $\mathrm{Cr}$ (Rai et al. 2013) and dichloromethane and dichloroethane (Wu et al. 2014). In the present study, Cd(II) stress could damage the biosynthesis of chlorophyll in C. vulgaris, which is in agreement with results of Küpper et al. (2003), Rai et al. (2013), and Çelekli et al. (2016). The increase of Chlorophyll $a / b$ suggesting that the $C h l b$ is more sensitive than $C h l b$ under $0.5 \mathrm{mg} \mathrm{L}^{-1}$, the decrease suggesting that cadmium can cause some Chl $a$ to be converted to $C h l b$ by oxidation of the methyl group on the ring II (Chettri et al. 1998).

The Carotenoid also decreased, $\mathrm{Cd}(\mathrm{II})$ ions had an adverse effect on the total carotene content. An adverse effect was previously reported for the carotene production by Ulva prolifera, U. linza (Jiang et al. 2013) and S. setiformis (Çelekli et al. 2016) under Cd(II) exposure.

The soluble protein content increased under $\mathrm{Cd}(\mathrm{II})$ stress. The increase of soluble protein is because of soluble protein is related to a variety of metabolic processes in cells, heavy metal stress can induce related stress protein gene expression, which is a defense mechanism of plants to environment stress (Xu et al. 2007).

$\mathrm{Cd}(\mathrm{II})$ stress enhanced the accumulation of hydrogen peroxide and superoxide anion in C. vulgaris. Increasing hydrogen peroxide and superoxide anion content of algae due to exposure of heavy metal has been previously studied by many researchers (Wu et al. 2014; Çelekli et al. 2016). One of the mechanisms that was involved 
in the prevention of metal-induced cell destruction has been the synthesis of antioxidative enzymes (Wu and Lee 2008). Elevated levels of antioxidant enzymes SOD, CAT, GR and POD in C. vulgaris following the Cd treatment in this study indicated that these enzymes could act in combination to reduce the impact of metal toxicity, the same results has reported in Acanthophora spicifera, Chaetomorpha antennina, and Ulva reticulate (Babu et al. 2014).

A concentration-dependent increase in antioxidant activity was observed in the present work, similar to the reported results in C. vulgaris (Bajguz 2010). Increased glutathione levels had been shown to correlate with plant adaptation to extreme metal stress, and decreased glutathione pool shows marked alterations in response to metal stress (Jin et al. 2008; Masood et al. 2012). Therefore, the increased glutathione level noted in C. vulgaris when treated with $\mathrm{Cd}$ under $0-1 \mathrm{mg} \mathrm{L}^{-1}$, that may precede phytochelatin accumulation by intracellular sequestration of metal ions (De Vos et al. 1992). And the decreased glutathione level showed in $C$. vulgaris when treated with $\mathrm{Cd}$ under 3-7 $\mathrm{mg} \mathrm{L}^{-1}$, similarly, exposure of $\mathrm{Cd}$ decreased glutathione of $A$. spicifera and exposure of $\mathrm{Cu}$ decreased glutathione of $\mathrm{C}$. antennina (Babu et al. 2014).

Induction of SOD activity in plant cells had been correlated with increased tolerance to a variety of chemical compounds and physical stresses (Mittler 2002). Induced SOD activity can either be due to the increased production of ROS or the protective measure adopted by macroalgae against oxidative damage. CAT is one of the key enzymes involved in the removal of toxic peroxides as it quenches $\mathrm{H}_{2} \mathrm{O}_{2}$ to water and molecular oxygen. In the present study, the increase in CAT activity can be considered as an adaptive mechanism developed by plants (Reddy et al. 2005). Reduction of CAT activity observed at the higher concentration of metals might be attributed to inactivation of enzyme by ROS, decrease in synthesis of enzyme, or change in the assembly of its subunits (Verma and Dubey 2003). POD also plays an important role in respiratory metabolism in plants. In the present study, the activity of POD increases with the increasing cadmium concentration until $5 \mathrm{mg} \mathrm{L}^{-1}$ and then begins to decrease.

\section{Conclusion}

Pollution in aquatic environments by metals has received considerable attention. Pollution of aquatic environments with heavy metals from natural water is a serious problem because of the toxicity of heavy metals to humans, fish and other live organisms. For this reason, pollution impact studies that focus on the aquatic environment are receiving more attention. This study confirmed that $C$. vulgaris showed a remarkable response to $\mathrm{Cd}(\mathrm{II})$ stress.
Cadmium stress caused a variety of toxicity to C. vulgaris, such as algal biomass, chlorophyll, protein content decreased, $\mathrm{H}_{2} \mathrm{O}_{2}$ and $\mathrm{O}_{2}^{--}$content increased. But C. vulgaris can adapt and regulation by changing the activity of SOD, POD, CAT and GR when subjected to cadmium stress in environment, thereby increasing the resistance to cadmium stress of $C$. vulgaris. Our research found that C. vulgaris has a high tolerance to cadmium. Hence, regulatory measures have to be taken by the authorities to limit the concentration of metal pollutants in the aquatic environment. This study also shows a range of physiological responses measured in this green alga under $\mathrm{Cd}(\mathrm{II})$ stress could be used as natural biomarkers or bioindicators of $\mathrm{Cd}$ contaminations in contaminated aquatic ecosystems.

\section{Authors' contributions}

JFC participated in the design of the study, and performed the statistical analysis. JRG and KWY performed the experiments. HCQ and ZYC helped to revise the manuscript. All authors read and approved the final manuscript.

\section{Author details}

${ }^{1}$ The College of Life Sciences, Northwest A\&F University, Yangling 712100, Shaanxi, China. ${ }^{2}$ College of Mechanical and Electronic Engineering, Northwest A\&F University, Yangling 712100, Shaanxi, China.

\section{Acknowledgements}

This study was supported by the National Natural Science Foundation of China (31000099), the Fundamental Research Funds of the Northwest A\&F University (2014YB038).

\section{Competing interests}

The authors declare that they have no competing interests.

Received: 4 May 2016 Accepted: 29 July 2016

Published online: 08 August 2016

\section{References}

Babu MY, Palanikumar L, Nagarani N, Devi VJ, Kumar SR, Ramakritinan CM, Kumaraguru AK (2014) Cadmium and copper toxicity in three marine macroalgae: evaluation of the biochemical responses and DNA damage. Environ Sci Pollut Res 21(16):9604-9616

Bajguz A (2010) An enhancing effect of exogenous brassinolide on the growth and antioxidant activity in Chlorella vulgaris cultures under metals stress. Environ Exp Bot 68:175-179

Bouzon ZL, Schmidt EC, de Almeida AC, Yokoya NS, de Oliveira MC, Chow F (2011) Cytochemical characterization and ultrastructural organization in calluses of the agarophyte Gracilariopsis tenuifrons (Gracilariales, Rhodophyta). Micron 42:80-86

Bradford MM (1976) A rapid and sensitive method for the quantity of protein dye binding. Anal Biochem 72:248-254

Çelekli A, Gültekin E, Bozkurt H (2016) Morphological and biochemical responses of Spirogyra setiformis, exposed to cadmium. CLEAN Soil Air Water 44(3):256-262

Chen H, Chen J, Guo Y, Wen Y, Liu J, Liu W (2012) Evaluation of the role of the glutathione redox cycle in $\mathrm{Cu}(\mathrm{II})$ toxicity to green algae by a chiral perturbation approach. Aquat Toxicol 120:19-26

Chettri MK, Cook CM, Vardaka E, SawidisT Lanaras T (1998) The effect of Cu, Zn and $\mathrm{Pb}$ on the chlorophyll content of the lichen Cladonia convoluta and Cladonia rangiformis. Environ Exp Bot 39:1-10

Dai HP (2012) Unraveling the mechanisms of cadmium tolerance and detoxifcation in Populus $\times$ Canescens. Northwest A\&F University, Shaanxi 
De Vos RCH, Vonk MJ, Vooijs R, Schat H (1992) Glutathione depletion due to copper induced phytochelatin synthesis causes oxidative stress in Silene cucubalus. Plant Physiol 98:853-858

Gao JF (2005) Plant physiology experimental guidance. Higher Education Press, Beijing, pp 211-218

Gülay BM, Yakup A (2011) Preparation of a composite biosorbent using Scenedesmus quadricauda biomass and alginate/polyvinyl alcohol for removal of $\mathrm{Cu}(\mathrm{II})$ and $\mathrm{Cd}(\mathrm{II})$ ions: isotherms, kinetics, and thermodynamic studies. Water Air Soil Pollut 221:391-403

Jiang HP, Gao BB, Li WH, Zhu M, Zheng CF, Zheng QS, Wang CH (2013) Physiological and biochemical responses of Ulva prolifera and Ulva linza to cadmium stress. Sci World J 3:94-106

Jin X, Yang X, Islam E, Liu D, Mahmood Q (2008) Effect of cadmium on ultrastructure and antioxidative defense system in hyperaccumulator and non-hyperaccumulator ecotypes of Sedum alfredii Hance. J Hazard Mater 156:387-397

Jozef K, Martin B (2007) Changes of phenolic metabolism and oxidative status in nitrogen-deficient Matricaria chamomilla plants. Plant Soil 297:255-265

Jozef K, Bořivoj K, Jana K, Martin B (2009) Physiology of Matricaria chamomilla exposed to nickel excess. Ecotoxicol Environ Saf 72:603-609

Juraj P, Eliza S, Jana K, Tatiana K, Martin B (2011) Influence of long-term exposure to copper on the lichen photobiont Trebouxia erici and the freeliving algae Scenedesmus quadricauda. Plant Growth Regul 63:81-88

Kováčik J, Klejdus B, Hedbavny J, Bačkor M (2010) Effect of copper and salicylic acid on phenolic metabolites and free amino acids in Scenedesmus quadricauda (Chlorophyceae). Plant Sci 178:307-311

Küpper H, Šetík I, Šetliková E, Ferimazova N, Spiller M, Küpper FC (2003) Copper-induced inhibition of photosynthesis: limiting steps of in vivo copper chlorophyll formation in Scenedesmus quadricauda. Funct Plant Biol 30(12):1187-1196

Liu H, Li L, Yin C, Shan B (2008) Fraction distribution and risk assessment of heavy metals in sediments of Mushui Lake. J Environ Sci 20:390-397

Lundholm N, Hansen PJ, Kotaki Y (2004) Effect of pH on growth and domoic acid production by potentially toxic diatoms of the genera Pseudonitzschia and Nitzschia. Mar Ecol Prog Ser 273:1-15

Luoma SN, Rainbow PS (2005) Why is metal bioaccumulation so variable? Biodynamics as a unifying concept. Env Sci Technol 39:1921-1931

Masood A, lqbal N, Khan NA (2012) Role of ethylene in alleviation of cadmiuminduced photosynthetic capacity inhibition by sulphur in mustard. Plant Cell Environ 35:524-533

Mittler R (2002) Oxidative stress, antioxidants and stress tolerance. Trends Plant Sci 7:405-410

Mohammed M, Markert B (2006) Toxicity of heavy metals on Scenedesmus quadricauda (Turp.) de brebisson in batch cultures. Environ Sci Pollut Res 13:98-104

Rai UN, Singh NK, Upadhyay AK, Verma S (2013) Chromate tolerance and accumulation in Chlorella vulgaris L.: role of antioxidant enzymes and biochemical changes in detoxification of metals. Bioresour Technol 136:604-609
Reddy MK, Alexander-Lindo RL, Nair MG (2005) Relative inhibition of lipid peroxidation, cyclooxygenase enzymes and human tumor cell proliferation by natural food colors. J Agric Food Chem 53:9268-9273

Romanowska E, Wróblewska B, Drożak A, Zienkiewicz M, Siedlecka M (2008) Effect of pb ions on superoxide dismutase and catalase activities in leaves of pea plants grown in high and low irradiance. Biol Plant 52(52):80-86

Schaedle M (1977) Chloroplast glutathione reductase. Plant Physiol 59:1011-1012

Schmidt ÉC, Nunes BG, Maraschin M, Bouzon ZL (2011) Effect of ultraviolet-B radiation on growth, photosynthetic pigments, and cell biology of Kappaphycus alvarezii (Rhodophyta, Gigartinales) macroalgae brown strain. Photosynthetica 48(2):161-172

Stanier RV, Kunisawa R, Mandel M, Cohen-Bazire G (1971) Purification and properties of unicellular blue-green algae (order: Chrococcales). Bacteriol Rev 35:171-205

Stork F, Backor M, Klejdus B, Hedbavny J, Kovacik J (2013) Changes of metalinduced toxicity by $\mathrm{H}_{2} \mathrm{O}_{2} / \mathrm{NO}$ modulators in Scenedesmus quadricauda (Chlorophyceae). Environ Sci Pollut Res 20:5502-5511

Sun Q, Hu JJ (2005) Plant physiology research technology. China, Northwest Agriculture and Forestry University Press, Shaanxi, pp 174-176

Verma S, Dubey RS (2003) Lead toxicity induces lipid peroxidation and alters the activities of antioxidant enzymes in growing rice plants. Plant Sci 164(4):645-655

Wellburn AR (1994) The spectral determination of chlorophylls a and b, as well as total carotenoids, using various solvents with spectrophotometers of different resolution. J Plant Physiol 144:307-313

Wu TM, Lee TM (2008) Regulation of activity and gene expression of antioxidant enzymes in Ulva fasciata Delile (Ulvales, Chlorophyta) in response to excess copper. Phycologia 47:346-360

Wu S, Zhang H, Yu X, Qiu L (2014) Toxicological responses of Chlorella vulgaris to dichloromethane and dichloroethane. Environ Eng Sci 31(1):9-17

Xu QJ, Jin XC, Wang XM et al (2007) Effects of different concentration ammonium-n on Hydrilla verticillata antioxidant enzymes under $\mathrm{Cd}$ stress. Chin J Appl Ecol 18(2):420-424

Xu D, Li C, Chen H, Shao B (2013) Cellular response of freshwater green algae toperfluorooctanoic acid toxicity. Ecotoxicol Environ Saf 88:103-107

Zhang XL, Shi GX, Xu N, Zeng XM (2002) Effects of mercury and cadmium on some of physiological indicators of Chara. J Nanjing Norm Univ 25(1):38-43

Zhang PY, YU J, Tang XX (2005) UV-B radiation suppresses the growth and antioxidant systems of two marine microalgae, Platymonas subcordiformis (Wille) Hazen and Nitzschia closterium (Ehrenb.) W. Sm. J Integr Plant Biol 47(6):683-691

Zhang W, Zhang M, Lin K, Sun W, Xiong B, Guo M, Cui X (2012) eco-toxicological effect of carbamazepine on Scenedesmus obliquus and Chlorella pyrenoidosa. Environ Toxicol Pharmacol 33:344-352

Zhou CF, Wu GR, Shi X et al (2001) The role of antioxidant system in $\mathrm{Cu}^{2+}$ stress resistance in Alternanthera philoxeroides. Acta Bot Sin 43(4):389-394

\section{Submit your manuscript to a SpringerOpen ${ }^{\circ}$ journal and benefit from:}

- Convenient online submission

- Rigorous peer review

- Immediate publication on acceptance

- Open access: articles freely available online

- High visibility within the field

- Retaining the copyright to your article

Submit your next manuscript at $\mathbf{s p r i n g e r o p e n . c o m ~}$ 